metodologiy (Project and logistics management: new knowledge based on two methodologies) // [I.O. Lapkina, V.O. Andrievskaja, V.U. Smrkovskaja and oth.] Vol. 2. Monograph. Odesa: KUPRIENKO SV. 170178 [in Ukrainian]. DOI. 10.21893/2616-8936.2019-02.

4. Petuhov V.S. (1970) Organizaciya morskih passazhirskih perevozok $v$ mestnom soobschenii (Organization of maritime passenger transportation in local communication). M: Transport. 152 [in Russian],

5. Shibaev A.G. (2013) Passazhirskije perevozki (Passenger transportation) / A.G. Shibaev, G.N. SiVvanskaja, I.M. Petrov. Odessa: Feniks. 336 [in Russian],

DOI https://doi.org/10.30525/978-9934-588-79-2-2.38

\title{
SCIENTIFIC METHODOLOGICAL APPROACH TO DETERMINING THE TYPE AND PARAMETERS OF CROSS-COUNTRY TRANSPORTATION
}

\author{
Mishchenko Ya. S. \\ $P h D$ in Technical Science, \\ Senior Lecturer at the Department of Armored Vehicles \\ Hetman Petro Sahaidachny National Army Academy \\ Kuprinenko O. M. \\ $P h D$ in Technical Sciences, Senior Scientist Researcher, \\ Head of the Department of Armored Vehicles \\ Hetman Petro Sahaidachny National Army Academy \\ Lviv, Ukraine
}

Dispute over which is better wheeled running or tracked running gear for cross-country transportation (CCT) continues today.

Means of transport with wheeled running gear in comparison with the tracked running gear have got better mileage rating and reliability (longer reserve maintenance period), much lower cost of production and operation, better adapted to traffic on surfaced road with higher speeds without destroying roads.

Considering the complexity of the mechanics of the interaction of the vehicles with the terrain [1], there is ambiguity in the choice of type and parameters of the CCT engine for their rational use in a particular geographical area. 
Analysis of existing scientific and methodological approaches to the choice of type and parameters of the engine during the designing of CCT showed that the type of engine is determined taking into account its purpose and mobility requirements. In this case, the criterion for selecting the type of engine is the value of the specific pressure in contact of the engine with the support surface, which is determined by the formula

$$
q_{s}=\frac{P_{z \max }}{S_{k}}
$$

where $\mathrm{q}_{\mathrm{s}}$ - is the pressure of the CCT through the contour area of the engine $\left(\mathrm{S}_{\mathrm{k}}\right)$ on the support surface, $\mathrm{Pa} ; \mathrm{P}_{\mathrm{zmax}}-$ maximum up load on the engine, $\mathrm{H}$.

This scientific and methodological approach is widely used in various fields of mechanical engineering for a long time [2-3].

The imperfection of existing approaches is as follows. Firstly, the value of soil-bearing capacity $\left(\mathrm{q}_{\mathrm{rp}}\right)$, given in the technical literature, are averaged and may differ from the real ones in specific areas of operation during the year [4]. Secondly, the experimental determination of $\mathrm{q}_{г р}$ involves the vertical indentation of the stamp in the soil [5], which differs significantly from the physical content of the process of movement of armored combat vehicle on different types of soils. Thirdly, the theoretical determination of $\mathrm{q}_{\text {гр }}$ by the formulas given in [4-5] is possible only for homogeneous soil types at different depths. Fourthly, the real physical and mechanical properties of soils at depths up to $0.5 \mathrm{~m}$ are different and depend on the humidity and density of the soil skeleton. The difficulty of determining the characteristics of the soil is the constant change in the values of their physical and mechanical properties in different geographical areas during the calendar year, which does not allow to take them into account accurately enough in the calculations.

Certain circumstances of training led up to the development of scientific and methodological apparatus, which can determine the reasonable parameters and type of manual CCT taking into account changes in viscoelastic power structures that spent a calendar year in a particular geographical area of their implementation.

To determine the values of soil deformation, instead of $\mathrm{q}_{\mathrm{rp}}$, it is proposed to use the soil deformation modulus $(E)$, which in physical significance does not depend on the size of the stamping tool and the depth of its deepening.

The essence of the suggested scientific and methodological approach is a logical and gradual selection of engine parameters for a specific geo- 
graphical area of operation of CCT and involves the implementation of such stages and calculations:

1. 1. Determining the type of soil, its mechanical composition, the maximum value of relative soil moisture at depths up to $0.5 \mathrm{~m}$ of the selected area of operation of CCT. Calculations are performed with an amount of $20 \mathrm{~mm}$ at the next value of the value of the depth of the propulsion into the ground.

2. Calculation of the outer diameter of the wheel by formula

$$
D(W, m)=\frac{\mathrm{F}_{z \max } \cdot \cos a}{\sqrt{k_{\mathrm{b}} \cdot \sqrt{1-k_{\text {д }}^{2}}} \cdot k_{h} \cdot h_{\max } \cdot\left(K_{E_{1}} \cdot \frac{\left.W_{T} \cdot\left(k_{\rho_{1}} \cdot m\right)^{k_{\rho}}\right)^{2}}{(W-0,05)}-K_{E_{2}} \cdot\left(W \cdot W_{T}\right)^{2}\right)}
$$

where $D$ - is the overall tire diameter, $\mathrm{m} ; F_{z \max }$ - maximum vertical load at the wheel, $\mathrm{H} ; k_{b}$-design factor of the tire; $k_{\partial}$ - deflection factor of tires; $h_{\max }$ - deformation of the soil surface, $\mathrm{m} ; k_{h}$ - coefficient of proportionality of ground distortion; $W$ - soil moisture; $W_{T}$ - liquid limit; $\rho_{\mathrm{c}}-$ particle specific gravity, $\mathrm{kg} / \mathrm{m}^{3} ; K_{E 1}-$ empirical coefficient, $\mathrm{m}^{5} / \mathrm{s}^{2} \cdot \mathrm{kg} ; K_{E 2}-$ deformation coefficient of soil, MPa.

3. Verification of the obtained values of the he overall tire diameter by formula

$$
1,3 \geq D \geq k_{h D} \cdot \mathrm{h}_{\max },
$$

where $k_{h D}=h / D=\left(f_{k} / a\right)^{2} ; h$ - is the ground distortion, m; $a$ - coefficient depending on the tire stiffness (within $0,6 \div 0,9$ ); $f_{k}$ - coefficient of rolling resistance, the value of which depends on the type of soil (for moist argil sand ground $-0,35 \leq f_{k} \leq 0,52$; for dry sand $-0,10 \leq f_{k} \leq 0,30$ ).

Due to formula (2) it is established that to ensure the movement of the wheeled armored combat vehicle forward and to overcome the force of rolling resistance $k_{h D} \leq 0,33$ - for argil sand ground; $k_{h D} \leq 0,11$ - for dry sand. Obtained by calculating the dependence of the values of the tire diameter $D$ on soil moisture $W$ at different depths $h$ at different loads $m$, as well as the range of rational values of $D$ are shown in Fig. 1 .

After determining all possible values of the overall tire diameter, the storage matrix is checked. If at least one value is obtained that meet the 156 
basic requirement, the width of tire section is calculated and the process of selecting the type of engine is considered completed.

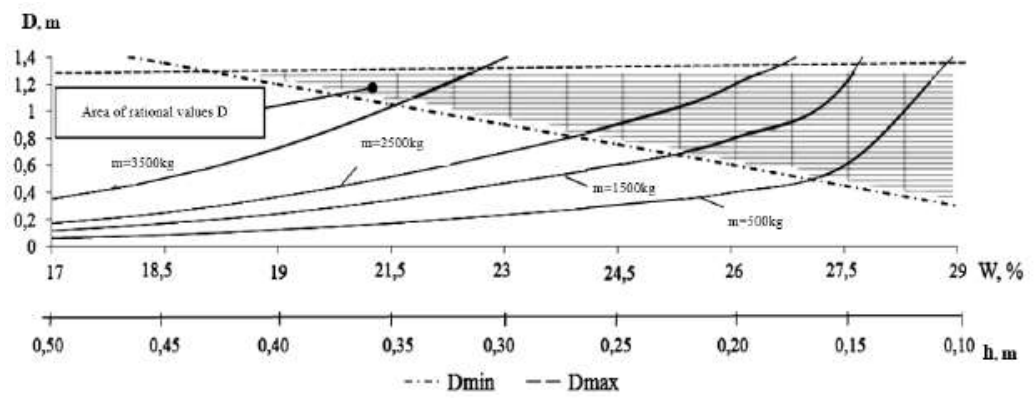

Fig. 1. Correspondence of the values of the tire diameter $D$ on soil moisture $W$ at different depths $h$ at different loads $m$

At the last stage, the filling of the matrix is checked. If the matrix is empty, then the parameters of the support surface of the tracked running gear are calculated according to the developed relation

$$
L(W, m)=\frac{F_{z \max }^{2} \cdot \cos a}{4 \cdot h_{\max }^{2} \cdot\left(k_{b_{1}} \cdot \ln \left(\frac{\mathrm{m}}{2}\right)-k_{\mathrm{b}_{2}}\right) \cdot \mathrm{k}_{2}\left(K_{E_{1}} \cdot \frac{W_{T} \cdot\left(k_{\mathrm{\rho} 3} \cdot m+k_{\mathrm{p}^{4}}\right)^{2}}{(W-0,05)}-K_{E_{2}} \cdot\left(W \cdot W_{T}\right)^{2}\right)^{2}}
$$

where $k_{b_{1}}=232,5 \mathrm{~mm} ; k_{b_{2}}=1747 \mathrm{~mm}$.

Using the relations (3), the rational values of the length of the support structure of the caterpillar track L are revealed. The obtained calculated values are checked by the condition of compliance of the coefficient of the maximum and minimum value of the co-relation of length and width on the basis of biogenic armored combat vehicle, determined for different types of full-track armored combat vehicle.

Resulting by calculating the correspondence of the values of the length of the supporting surface of the tracked running gear $L$ on soil moisture $W$ at different depths $h$ at different loads $m$, as well as the range of rational values of $L$ are shown in Fig. 2.

The offered scientific and methodological approach was tested during the determination of the type and parameters of the engine of CCT for operation in Western Ukraine. 


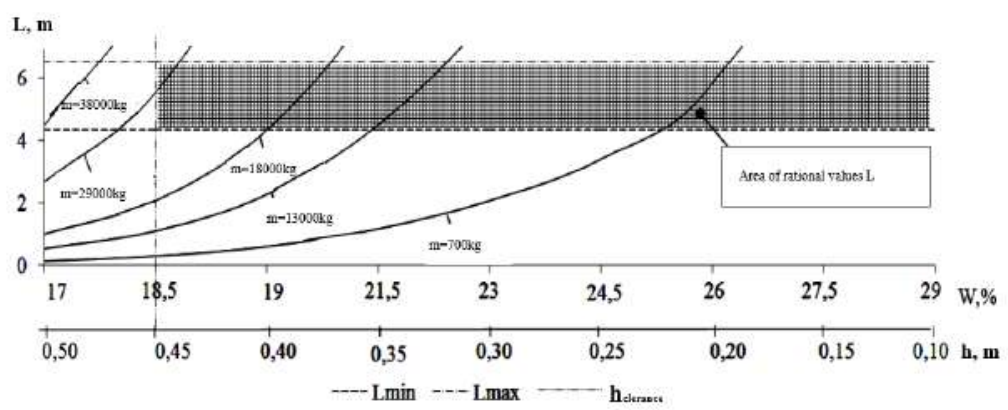

Fig. 2. Correspondence of values of length of a supporting surface of a tracked running gear $L$ on soil moisture $W$ at different depths $h$ at different loads $m$

Therefore, the offered scientific and methodological approach, in contrast to the known ones, takes into account the peculiarities of changes in the physical and mechanical properties of the soil of the CCT operation area at depths up to $0.5 \mathrm{~m}$ at different engine loads during the year in any geographical area of the world and allows to determine the type and parameters of engine at the stage of their development.

\section{References:}

1. Wong J.Y. Terramechanics and Off-Road Vehicle Engineering. Butterworth-Heinemann, 2009, 488 p. https://doi.org/10.1016/C2009-0-00403-6.

2. Казаченко Г.В., Басалай А., Кремчеев Э.А. Колёсные движители горных машин. Минск, 2012. 37 с.

3. Лебедєв А.Т., Антощенков В.М., Бойко М.Ф. та ін. Трактори та автомобілі. Ч. 3. Шасі : навч. посібник. Київ, 2004. 334 с.

4. Агейкин Я.С. Вездеходные колёсные и комбинированные движители. Москва, 1972. 184 с.

5. Вольская Н.С. Разработка методов расчета опорно-тяговых характеристик колесных машин по заданным дорожно-грунтовым условиям в районах эксплуатации: дис. д-ра техн. наук. Московский государственный технический университет. Москва, 2008. 370 с. 